\section{BIOGEOGRAPHY}

\section{Migration} encoded in teeth

Ancient human teeth tell a story of Europeans migrating to Eastern Asia during the Bronze Age, roughly 3,000 years ago, and mixing with local populations.

Human lower canines usually have only one root, but two-rooted canines occur in 5-8\% of Europeans and occasionally in some Asian populations. Christine Lee at the Chinese Academy of Sciences in Beijing and Richard Scott at the University of Nevada in Reno examined the frequency of the dental trait in human skulls ranging between 60 and 6,000 years old from Spain and Eastern Asia. They found traces of two-rooted canines in up to $4 \%$ of skulls in regions of Mongolia and China. The researchers conclude that the rare trait was probably introduced into Eastern Asia by Indo-European groups crossing the western frontier of China and Mongolia.

Am. J. Phys. Anthropol. http:// dx.doi.org/10.1002/ajpa.21585 (2011)

\section{NEUROSCIENCE}

\section{A taste map of the brain}

Four of the five basic tastes bitter, salty, sweet and umami - are processed at different hot spots in the brain.

Charles Zuker at Columbia University in New York and his colleagues used fluorescence microscopy to image neural activity in the partially exposed brains of anaesthetised mice while administering different-tasting chemicals to the animals' tongues. The images show discrete regions of neural activity in the primary taste cortex, each specific to a particular taste category and responsive to a range of chemicals within that category.

The authors could not pinpoint a hot spot for sour taste; they think that it may be outside the brain areas studied, or that acid stimuli act on other pathways, such as that for pain. The map could help researchers to understand how taste perception is integrated with other brain functions such as emotion and feeding behaviour, the authors say. Science 333, 1262-1266 (2011)

\section{CONSERVATION}

\section{Saving species with stem cells?}

Just seven northern white rhinoceroses remain - all in captivity - but could stem cells made from their tissues one day boost the animal's ranks?

Jeanne Loring at the Scripps

Research Institute in La Jolla,

California, and her team treated connective tissue cells from a 10-year-old female (Ceratotherium simum cottoni) with viruses that delivered four key human genes. The genes reprogrammed the adult cells into cells known as induced pluripotent stem cells (iPS cells). The authors used the same procedure to obtain iPS cells from the adult cells of an endangered drill monkey (Mandrillus leucophaeus).

The reprogrammed cells from both creatures generated the three different germ layers that give rise to all other tissues. The authors say that iPS cells from endangered animals could one day be used to make germ cells, such as sperm, for assisted captive breeding (see 'Stem cells spawn sperm cells'). Nature Methods http://dx.doi. org/10.1038/nmeth.1706 (2011)

\section{ELECTRONICS}

\section{A waterproof memory device}

As anyone who has spilled coffee onto their computer knows, electronics are highly susceptible to water damage. Kijung Yong and his team at Pohang University of Science and Technology in South Korea demonstrate a possible solution: a resistive switching

COMMUNITY CHOICE

The most viewed papers in science

\title{
DEVELOPMENTAL BIOLOGY
}

\section{Stem cells spawn sperm cells}

\section{HIGHLY READ \\ on www.cell.com in August}

Mouse stem cells can be transformed into reproductive tissue able to churn out sperm. Mitinori Saitou and his colleagues at Kyoto University in Japan coaxed embryonic stem cells into forming a type of cell called an epiblast, which is found in developing embryos.

Reprogrammed stem cells were also able to do this. Subsequent treatment of these epiblasts with a cocktail of proteins and nutrients converted them into the germ cells that make sperm.

The authors implanted these cells into the testes of mice lacking their own germ cells. After 10 weeks, the testes of some of the animals generated sperm, which, in turn, fertilized eggs to create healthy male and female mice. A similar approach with females might provide a renewable source of egg cells. Cell 146, 519-532 (2011)

memory chip that uses a layer of zinc oxide nanorods as the switching material. The application of stearic acid to the nanorods makes the material hydrophobic.

Water droplets placed on the device remained almost spherical and the device continued to function for many on-off cycles. Water on an unmodified version tended to spread, and the device broke. Adv. Mater. http://dx.doi. org/10.1002/adma.201101580 (2011)

\section{Competition counts}

Attempts to reduce ecosystem damage by removing an invasive species that has become an area's top predator can allow populations of invasive prey species to grow, inadvertently worsening matters. Wendy Ruscoe at Landcare Research in Lincoln, New Zealand, and her colleagues report that changes among species that compete for resources such as food could have similar consequences.
In the forests of $\mathrm{New}$ Zealand's North Island, the team monitored populations of stoats (Mustela erminea; pictured left), the rat (Rattus rattus) that they prey on and one of the rat's competitors, the Australian brushtail possum (Trichosurus vulpecula; right) - all invasive species. When the authors killed off the possums, rats jumped in number. However, controlling the stoats had no effect on the rat population, indicating that competition was more important than predation.

The team suggests that the benefits of controlling possum numbers should be weighed up against the consequences of increased rat numbers.

Ecol. Lett. http://dx.doi. org/10.1111/ j.1461-0248. 2011.01673.x (2011)

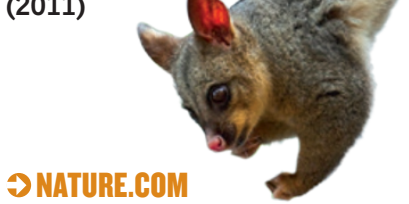

For the latest research published by Naturevisit: www.nature.com/latestresearch 